\title{
HEALTH SAFETY AND LIFE PROTECTION COVERAGE IN THE SOCIAL ECONOMY SECTOR IN GREECE: ANALYSIS OF EMPIRICAL FINDINGS
}

\author{
Dr.Mary Geitona, University of Thessaly, Department of Economics, Greece, \\ geitona@uth.gr \\ Lorena Androutsou, University of Thessaly, Department of Economics, Greece. \\ landroutsou@gmail.com
}

\begin{abstract}
In the past decade, there has been a growing interest in reinforcing the role of social economy in Greece, due to significant changes in the labor market, the economic recession and the public sector failure to cover social needs. Given the fact that there is limited research literature on this topic, the aim of this paper is to determine the implications of the social economy sector in Greece on the current economic conditions. It will also discuss employees' and volunteers' status and their social insurance coverage in terms of their health safety and life protection. The findings of two studies carried out by the Department of Economics of the University of Thessaly are analysed and criticised. The population sample in both studies included farmers' organisations, cooperatives, non-profit associations, consumer organisations, environmental organisations, associations representing the family and persons with disabilities, nongovernmental organisations, social enterprises and foundations. In addition, their main activities were health care, social care, culture, education, environment, entrepreneurial and education activities.
\end{abstract}

According to the results of both studies, it seems that social sector contributes to an annual $10 \%$ creation of new posts of employment. $21.5 \%$ of the employees are fully covered by social insurance and are also eligible for occupational health and safety, while $9.9 \%$ work as part-timers and are also covered and eligible for health care, even though they face severe restrictions regarding their retirement rights. However, $68.6 \%$ of people involved in the third sector are volunteers who do not have a permanent job, they are not covered by social insurance and are not eligible for occupational health and safety. Also, there are no retirement rights for them. Consequently, it seems that social economy in Greece, does not promote a safe and healthy working environment by providing to volunteers 
occupational health and safety, including the avoidance of job related injuries and professional diseases.

It is believed that if the reform already announced becomes active, numerous positive changes will occur in the performance of the third sector. New work places will be created, competitiveness of the public sector monopoly will be increased as well as social cohesion and social capital will be further reinforced. Moreover, the quality of employment by preventing occupational accidents, the expansion of social coverage to volunteers and the reinforcement of the volunteerism will be finally achieved. Further expected synergies will be the reduction of unemployment, economic growth and eventually the overcome of the economic crisis.

Key Words: Social Economy, Third Sector, Volunteerism, Health Safety, Greece

\section{INTRODUCTION}

Nowadays, in an era of economic recession, social economy is internationally one of the main issues in public policy. The reason for this is that social economy fights social exclusion and unemployment. People who do not have the necessary qualifications and work experience gain the opportunity to return to work or to find work (Byrne 1999). Moreover, deindustrialization in many European countries has limited the permanent, full time and formal work (Rifkin 1995). Uncertain and informal employment is increasing in an effort of the private sector to minimise labour costs. Similarly, employment uncertainty is also increasing in the public sector with significant workplace losses. As a result, most European countries face the deregulation of their labour market and the privatisation of their public sector.

Under these circumstances, the social economy appeared to be the best option as an additional source of employment, since it generates jobs and entrepreneurship by meeting social needs and very often by deploying the socially excluded (Smith and Lipsky 1993, Amin et al.2002). The social excluded groups and individuals, abandoned by the government or the private sector, could only survive by providing services in the field of the informal - black economy or in the social economy sector (Catterall et al. 1996; Borzaga and Maiello 1998). Social economy refers to a third sector in economies that lies between the private and the public sector. It includes organisations such as cooperatives, mutuals, associations, foundations, social enterprises, NGOs and charities. Diverse groupings are bound together by their sense of duty towards the members whose interests they represent.

Social economy is considered to be the provider of services for the socially excluded individuals; it gives them employment, covers their needs for social protection and makes them active members of the society (Borzaga kaı Maiello 
HEALTH SAFETY AND LIFE PROTECTION COVERAGE IN THE SOCIAL ECONOMY SECTOR IN GREECE: ANALYSIS OF EMPIRICAL FINDINGS

1998; Lipietz 1992 kal 1995, Ryan 1999). Social protection needs include services to vulnerable population - such as the children and the third age - to homeless, immigrants, drug dependent individuals, single mothers and people with special needs. Social economy also cares for continuing education of the unemployed and guarantees a viable natural environment.

Social economy activities are non profit and strengthen the economic affordability of people in need through the creation of diverse social networks and collective engagement (Putnam 1993, Rimke 2000). As agents for completion of social needs and for social integration, the social economy organisations are considered to be the main sources of social capital. They contribute to the wellness of institutions which are placed between the individual and the state and to the promotion of social values such as social responsibility and solidarity, social cohesion, the sense of obligation and social commitment, freedom of membership, participation and autonomy and finally, democratic management (Rimke 2000, Rifkin 2000, Amin et al.2002). Although the legal nature of social economy organisations differs from country to country, they are all inspired by the above mentioned common social values. According to international literature, the development of social economy contributes significantly to economic growth of and to the creation of new posts of employment in each country, the promotion of innovative social and entrepreneurial activities, the enhancement of citizens' trust and employees' satisfaction (Rimke 2000, Asmin et al. 2002 ). Additionally, it has been reported that the social economy sector reveals more flexible management and regulation of labour relations. For example, in France, social economy represents $12 \%$ of employment and contributes to $12 \%$ of GDP and in Spain $18 \%$ of employment and $14 \%$ of GDP respectively. (Salamon 1995, Archambault 1997, Alexander 1998, Zimmerck 1998). In the European Union social economy represents $8 \%$ of all employment and over 9 million people are employed in this sector (before the enlargement in 2004). In addition, the third sector is affecting $25 \%$ of the European population (Donoghue 1998, Giddens 2000). It is expected that social economy will increase in Europe in the forthcoming decades since the European Union promotes third sector entrepreneurial activities and reinforces employment in this field. More specifically, in their papers Borzaga and Maiello as well as Ruddle and Mulvihill in 1998 and 1999 respectively, criticise welfare systems, employment and the role of social enterprises in the European countries. They report the major evolutions experienced by social enterprises across Europe and the key challenges they are facing. Moreover, they provide an optimistic detailed analysis of different EU countries in terms of the third sector entrepreneurial activities promotion and employment reinforcement. (Borzaga and Maiello 1998, Ruddle and Mulvihill 1999)

\section{SOCIAL ECONOMY IN GREECE: A CRITICAL ANALYSIS}

In the past decade, there has been a growing interest in reinforcing the role of social economy in Greece, due to significant changes in the labor market, the economic recession and the public sector failure to cover social needs. Given 
the fact that there is limited research literature on this topic in the country, the aim of this paper is to determine the implications of the social economy sector in Greece on the current economic conditions. Additionally, it will discuss employees' status and their social insurance coverage in terms of their health safety and life protection.

In order to analyse the social economy status in the country, we considered the findings of two studies that have been carried out by the Department of Economics of the University of Thessaly. The first study was conducted in 2004 and was a cross sectional study, entitled "Social Economy Sector in Greece". 150 questionnaires were completed by the heads of the more established social economy organizations (Geitona et al.2006). The second study, entitled "Social Economy Sector in the region of Thessaly" was conducted in 2006 by collecting 113 questionnaires of the organizations involved in social economy activities in Thessaly (Zouboulakis et al.2006). The population sample in both studies included farmers' organisations, cooperatives, non-profit associations, consumer organisations, environmental organisations, associations representing the family and persons with disabilities, non-governmental organisations, social enterprises and foundations. In addition, their main activities were health care, social care, culture, education, environment, entrepreneurial activities and education exercising.

According to both studies' results, the basic characteristics of the social economy sector are the non-profit provision of services to the members and to the community so as to ensure the sharing of social and economic surpluses. Moreover, social ownership, independent management as well as empowerment and social responsibility constitute one of its major advantages. Additionally, people have priority over capital and are engaged with direct participation in the decision making through the one person one vote process. The above mentioned characteristics are also reported in other studies that have taken place in Greece (Ziomas 2001, Chrisakis and Ziomas 2002, Zannis 2002).

In an effort to determine the implications of the social economy sector on employment and to investigate its employees' social insurance coverage, we focused our research interest on employees'occupationall status, their health safety and life protection. Similar study results have not yet been presented elsewhere. Some of our descriptive results are presented in the following graphs and tables. Graph 1 shows that diverse and multiple activities allocated in the social economy sector whereas health and social care are covering the majority of activities. Healthcare activities referred to the provision of the medical care, prevention, consultation for people in need, such as the elderly, children, uninsured, refugees, and disabled individuals. Social care activities provide home-based services for the homeless, the disabled, orphans etc,. Cultural activities are related to the promotion of literature, history, theatre, monuments visits etc. Environmental social economy refers to the green economy, the environmental protection, recycling, energy consumption and waste pollution. The entrepreneurial activities put effort on the social enterprises and 
cooperatives, and finally the educational activities include continuing education, health education and prevention, life style changes etc.

It is worth mentioning that despite the universal coverage of the Greek population in the provision of health and social care from the public sector, the majority of social sectors activities are focused on health and social care. An explanation given to this finding might be that the population needs seem not to be faced by the National Health (NHS) and the National Social Care Services.

\section{Graph 1: Social economy activities at national level}

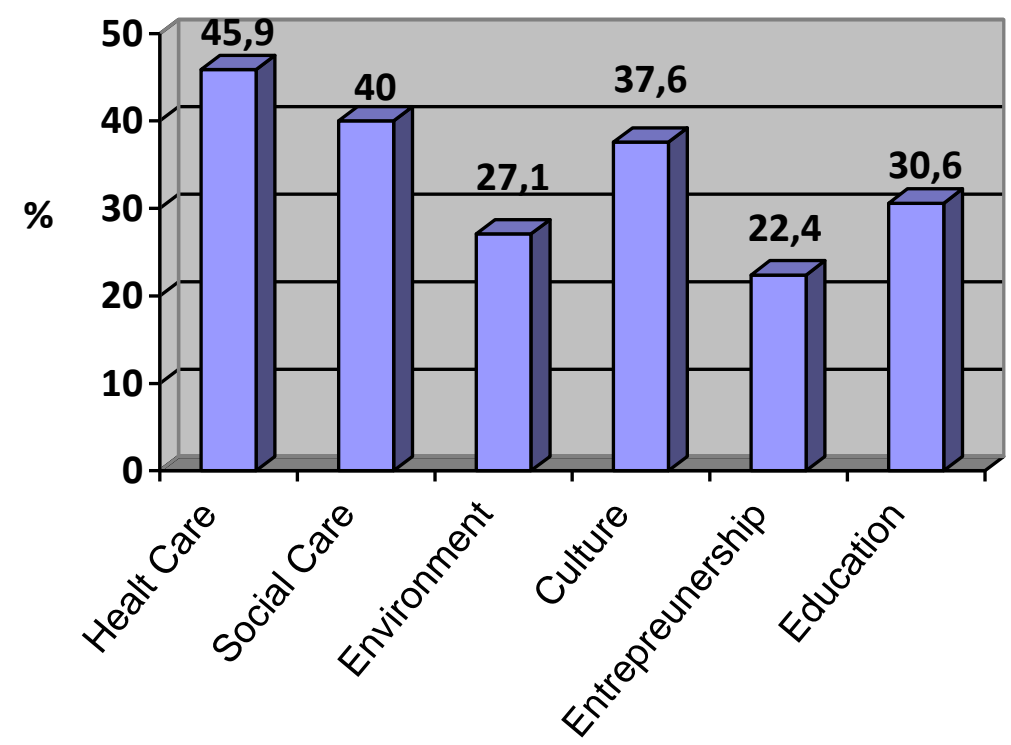

The degree of satisfaction of the legal representatives regarding the attainment of the goals of the social economy organizations seems to be very high reaching at $87 \%$ (Graph 2). More specifically, in the question posed to the legal representatives of each social economy organization such as administrators, governors, managing directors regarding the attainment of their goals, the majority answered that were satisfied in achieving their goals. 


\section{Graph 2: Degree of Objectives' Achievement}

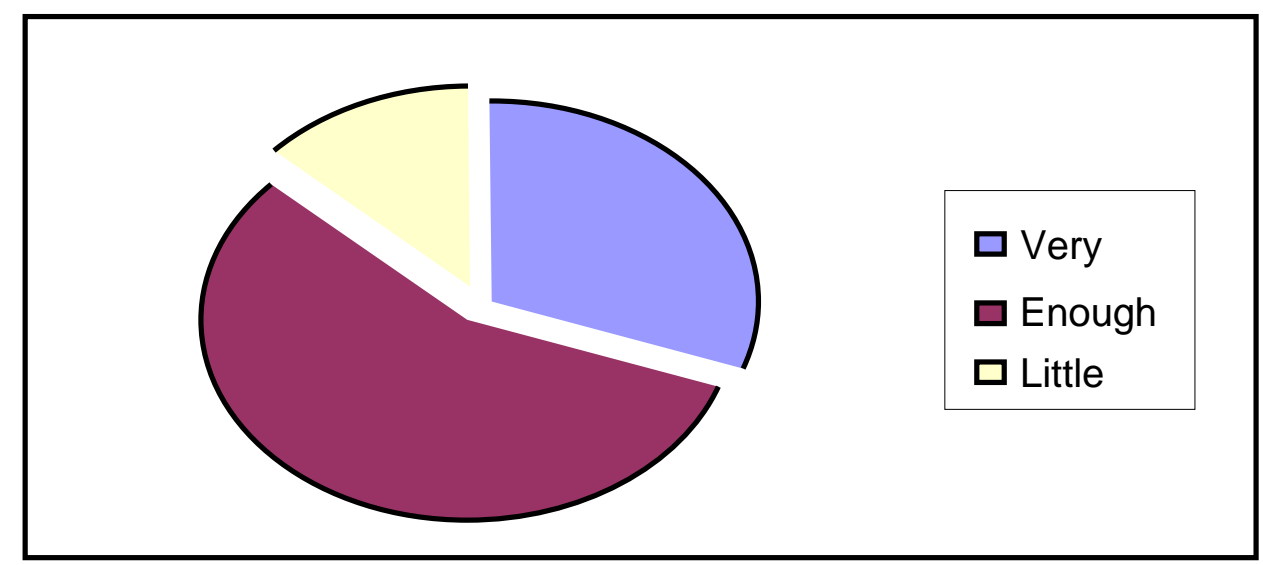

In order to quantify the number of individuals employed by the social economy sector of our sample by excluding volunteers (Graph 3 ), some figures help to give a clear picture: $20.7 \%$ of social organizations do not employ any individuals on a permanent, full or part time basis, $28.7 \%$ employ $1-9$ individuals, $36.8 \%$ employ $10-49 \%$ and $13.8 \%$ employ more than 50 people respectively. According to our findings it is revealed that the majority of social enterprises employ from 10 to 49 individuals regardless the employment status. It is also worth mentioning that the operation and activities of $20.7 \%$ of the social economy organizations are based on volunteers.

\section{Graph 3: Number of employees}

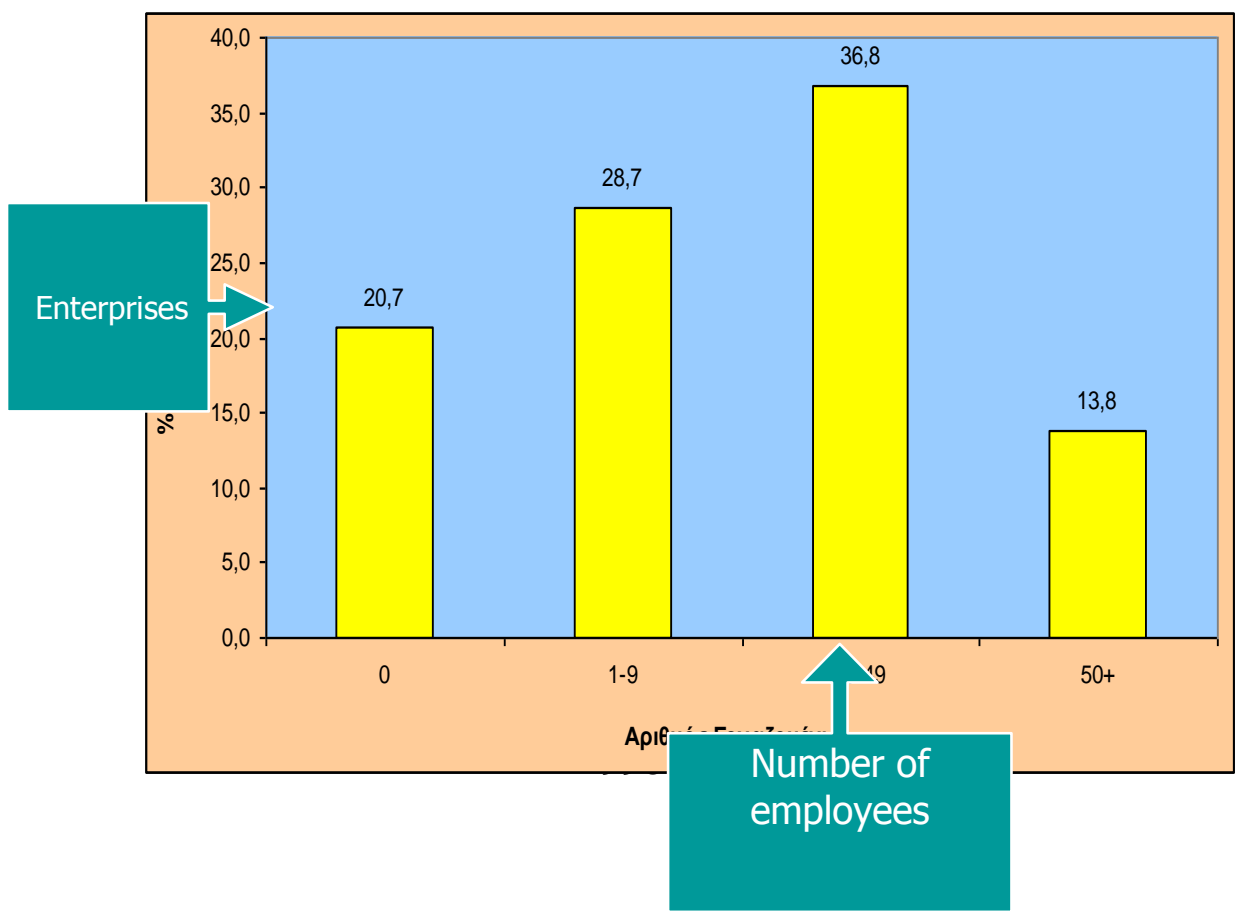


Given that one of the most important objectives of the social economy is to recruit people in need according to societal criteria, a question was posed regarding the recruitment of their target population. Target population includes individuals in need, mostly coming from disadvantaged and vulnerable social groups, people who usually have more difficulties in finding a job, for example single mothers, disabled people, orphans, homeless, unemployed, prisoners, chronically ill etc. It is crucial to mention that $57.6 \%$ of the social economy sector reported recruitment of its target population (Graph 4). This finding is also very important in terms of social inclusion criteria introduced by the social economy sector.

\section{Graph 4: Recruitment of the target population}

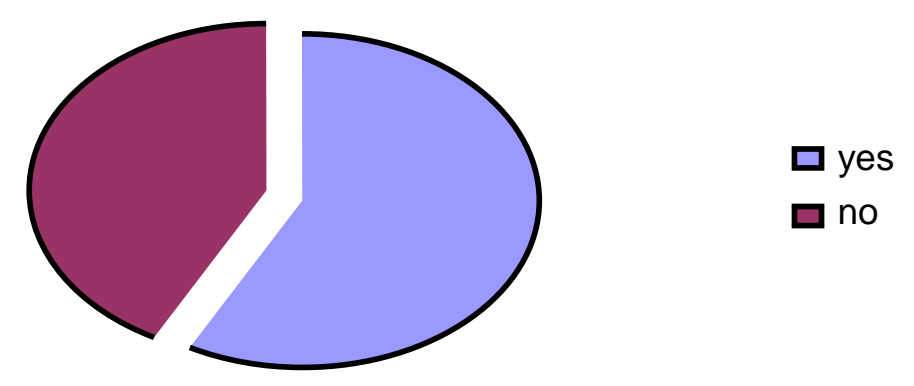

According to the results of the Geitona et al. study, as shown in Graph 5, the mean wage for full time employment is estimated at 1,100 euros per month whereas the majority of both full and part timers are paid in between 500 to 1,000 euros monthly. Similarly, the results of the Zouboulakis et al. study (Graph 6) referred to the specific geographical region. It must be mentioned that the wages in the first study are higher when compared to the wages of the second study. This differentiation is due to the fact that in the Geitona et al. study the sample constituted from the most established and well known social economy agents across the country, while in the Zouboulakis et al. study the sample only included local agents. 


\section{Graph 5: Personnel Wages per Month in euros (1st study)}

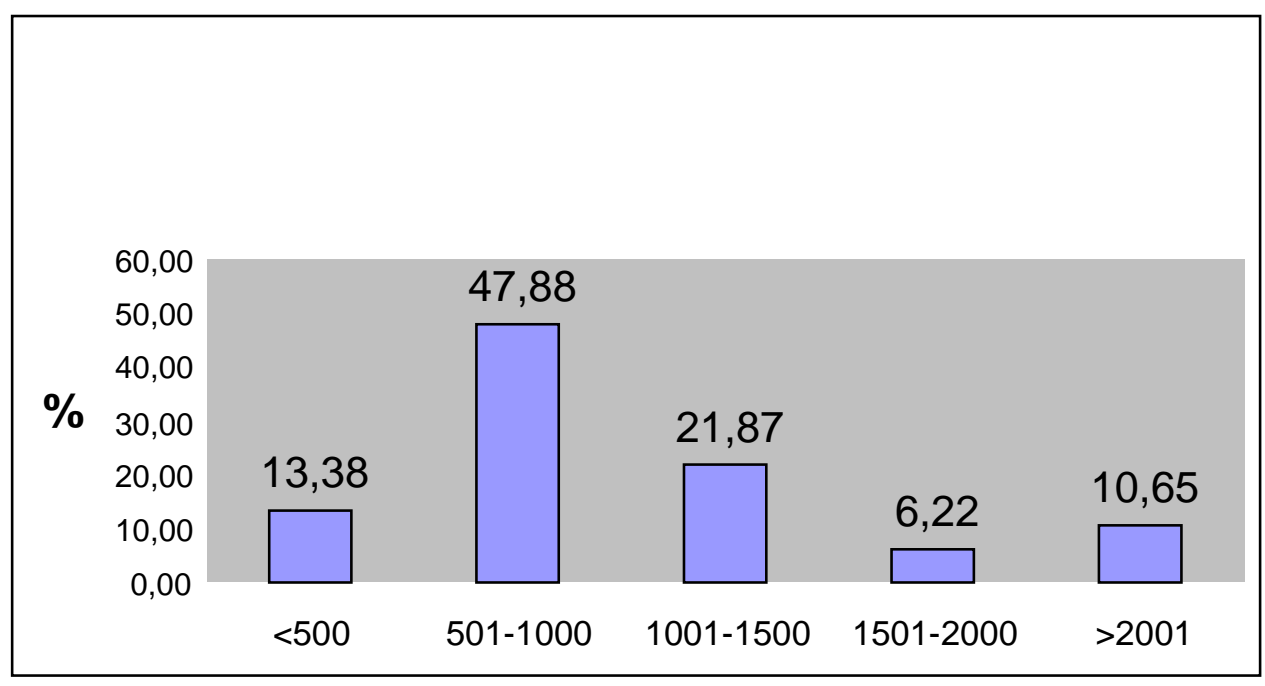

Graph 6: Personnel Wages per Month (2st study)

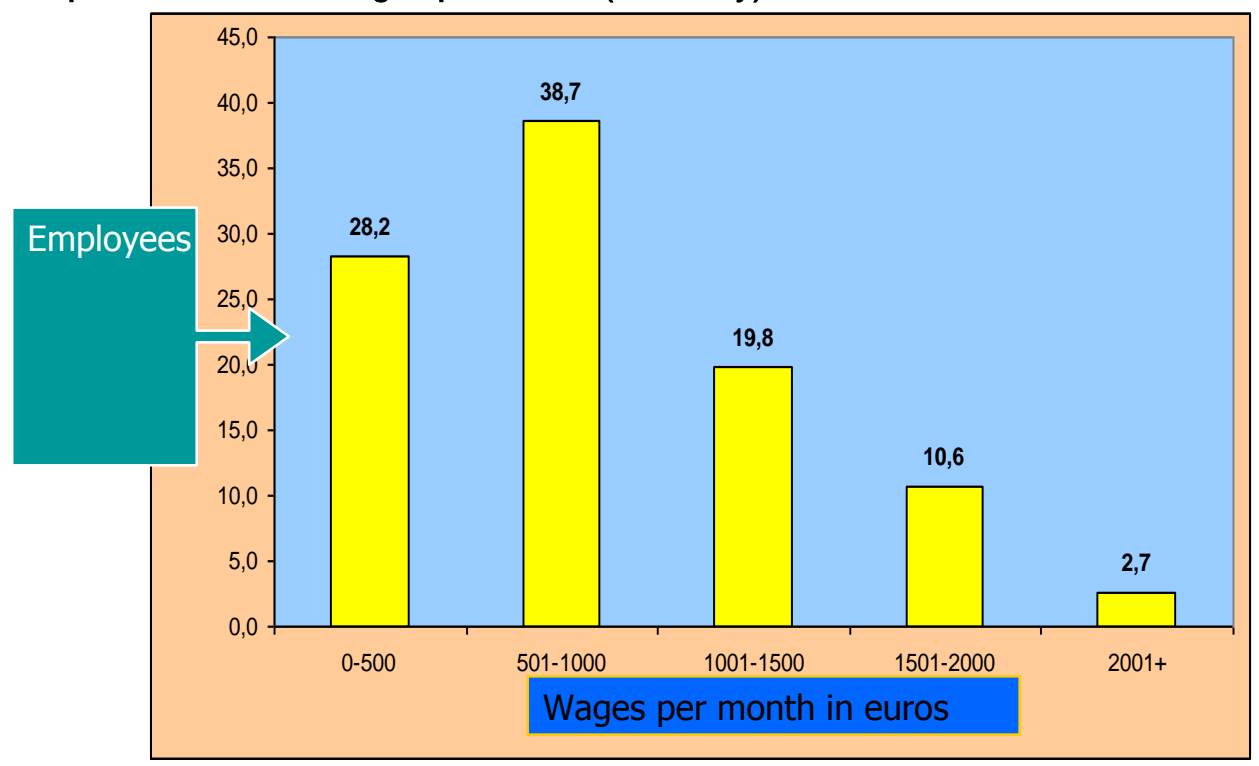

According to our findings, despite the fact that $62 \%$ of the social economy representatives are willing to collaborate with the public sector organisations, 
$78 \%$ of the respondents declared that public administration restricts seriously their expansion through bureaucratic procedures (Graph 7).

\section{Graph 7: Degree of restriction of public administration}

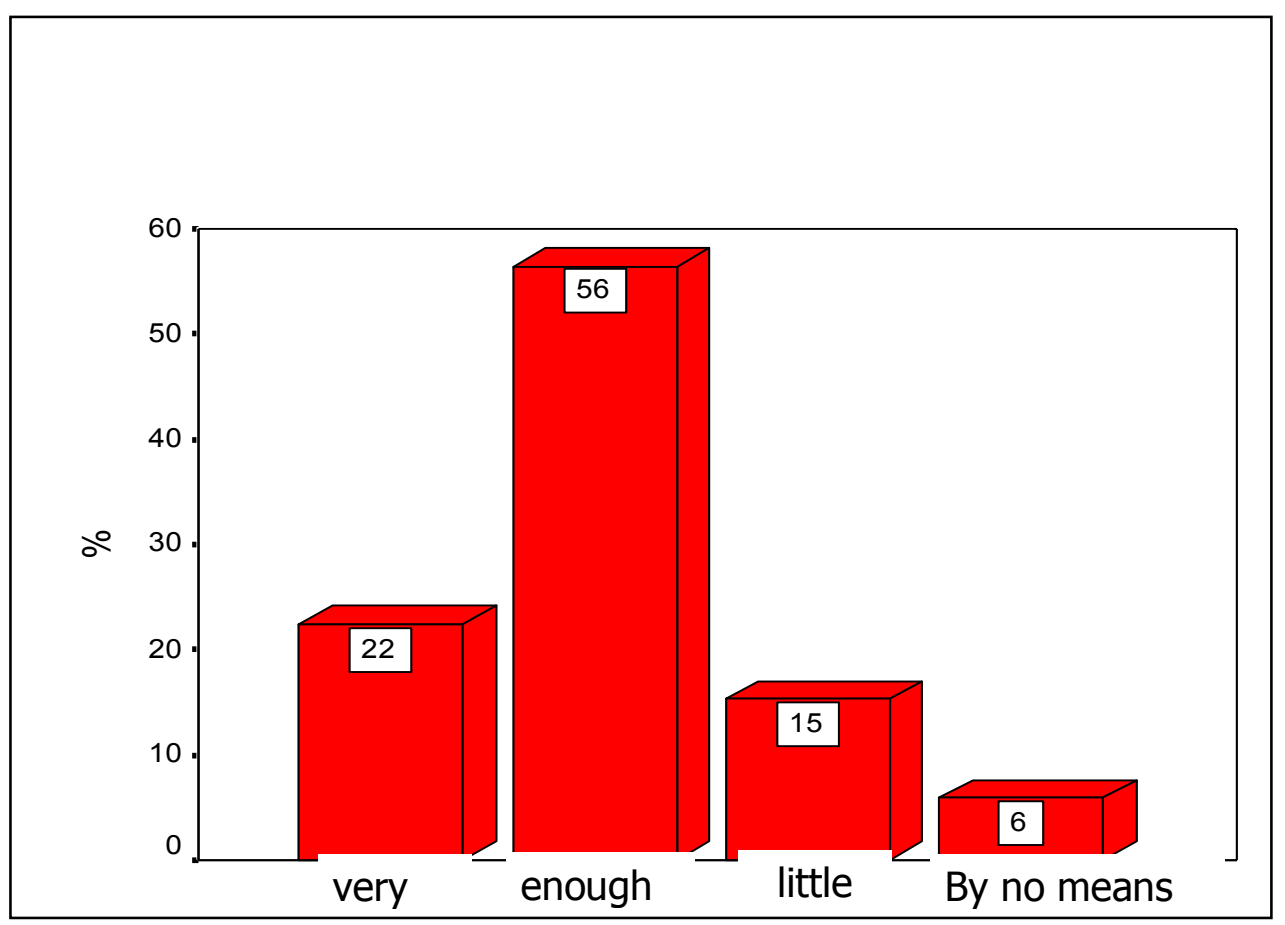

In an open question regarding the potential advantages or disantvantages of the social economy in the country, leaders' opinion is analytically presented in the Table 1 . The majority believes that numerous positive characteristics are incorporated in this sector, contributing to the provision of more social and economic benefits than the public or private sector bodies provide. More specifically, the most positive characteristics reported by the administrators, governors or legal representatives are firstly, the flexible management which accounts for the highest percentage of $93 \%$ and secondly, the encouragement of volunteerism accounting for almost $90 \%$. As demonstrated in the table, they decline managerial and bureaucratic criteria faced by the public administration, whereas they prefer criteria mostly met in the private sector, such as decentralization and autonomy in the decision making, motivation, citizens' trust etc. 
Table 1: The characteristics of Social Economy Institutions ( in \%)

\begin{tabular}{|l|c|c|c|}
\hline \multicolumn{1}{|c|}{ Advantages } & Positive & Indeferent & Negative \\
\hline Confidence of citizens & 72,9 & 24,7 & 2,4 \\
\hline Flexible management & 92,9 & 4,7 & 2,4 \\
\hline Motives - tax reduction & 71,8 & 24,7 & 3,5 \\
\hline Low operational costs & 77,6 & 21,2 & 1,2 \\
\hline Flexible labour regulations & 61,2 & 34,1 & 4,7 \\
\hline $\begin{array}{l}\text { Lower cost of social services provision than } \\
\text { those of the public sector }\end{array}$ & 49,4 & 49.4 & 1,2 \\
\hline Lower prices of goods than the private sector & 54,1 & 41,2 & 4,7 \\
\hline Encouragement of voluntaerism & 90,6 & 8,2 & 1,2 \\
\hline $\begin{array}{l}\text { Exploitation of existing structures of the public } \\
\text { sector }\end{array}$ & 54,1 & 41,2 & 4,7 \\
\hline $\begin{array}{l}\text { Promotion of innovative activities and creation } \\
\text { of new places of work }\end{array}$ & 89,4 & 9,4 & 1,2 \\
\hline $\begin{array}{l}\text { The self-governing of institutions and } \\
\text { autonomy in their management }\end{array}$ & 76,5 & 21,2 & 2,4 \\
\hline Reinforcement of the decentralisation & 74,1 & 20,0 & 5,9 \\
\hline
\end{tabular}

As mentioned before, the aim of this paper is to focus our research findings on the employment status of the social economy personnel and its social insurance coverage in terms of their health safety and life protection. Briefly, according to our results from the total 8,395 people professionally involved in the social economy sector in Greece, 1,595 people work on a permanent full-time basis, 611 as part-timers and 4,499 as full time and 992 as part-time volunteers. Regarding the employment of the disadvantaged people who belong in the target group and have been employed by the relevant social economy agents, our results revealed that 213 people are under the regime of full time employment, 218 are part timers and 267 are volunteers.

However, a further 14.185 people benefited by other activities of the social economy sector.

A more in depth analysis of the same results shows that 1,403 work posts refer to new posts of employment. This means an annual $10 \%$ creation of new posts. From the total 8,395 people, 1,808 permanent employees are fully covered by social insurance and are also eligible for occupational health and safety. Additionally, 829 employees work as part-timers and are also covered and eligible for health care, even though they face severe restrictions regarding their 
HEALTH SAFETY AND LIFE PROTECTION COVERAGE IN THE SOCIAL ECONOMY SECTOR IN GREECE: ANALYSIS OF EMPIRICAL FINDINGS

retirement rights. However, a number of 5,758 volunteers are not totally covered by social insurance and are not eligible for occupational health and safety. Also, there are no retirement rights for them. Consequently, quantitative and qualitative investigation of our results has shown that in the social economy sector in Greece, $68.6 \%$ of employees are volunteers who do not have a permanent job, they are not covered by social insurance and are not eligible for occupational health and safety. Consequently, the third sector in the country does not promote a safe and healthy working environment by providing to volunteers occupational health and safety, including the avoidance of job related injuries and professional diseases.

It is also believed that further research has to be conducted in order to have a more analytical aspect of the occupational conditions of the individuals working in this field. Up to now most studies -including this one- provide a holistic overview of social economy in the country, in terms of the clarification of social economy sector and its role in the economic growth and the political system, the determination of the enterprises - agents incorporated, the appropriate criteria for inclusion in the third sector, their proprietary status, financing etc (Chrisakis et al. 2002, Ziomas 2001, Zannis 2002). This is the reasoning behind which we attempted to further analyze our research findings. Our primary research hypothesis was not the employees' occupational safety and health protection as well as their working conditions. Having acknowledged the above mentioned methodological restrictions, our paper constitutes the first report referring to the lack and the unequal provision of employees' and volunteers' social protection rights.

\section{CONCLUDING REMARKS AND SUGGESTIONS}

Even though our research results are not optimistic regarding the social economic sector in Greece, two important socioeconomic advantages should be underlined. The first is referred to the Greek citizens' trust that seems to be higher than employees' satisfaction and the second that social economy sector contributes annually to a $10 \%$ of new posts of employment. Both findings are quite encouraging, if the economic situation of the country is taken under consideration. Both studies have been carried out in an era before the economic crisis. More precisely, when the economic growth was $3 \%$ to $4 \%$, the unemployment rate at $9 \%$, the public deficits reached $3 \%$ of GDP, public debt $117.2 \%$ of GDP and both the public and private debt reached $150 \%$ of GDP.

It is expected that the economic situation of the country will worsen after the economic crisis. According to OECD projections, it is estimated that an annual negative economic growth accompanied with a higher unemployment rate over $11 \%$ and public deficits will exceed $4 \%$ of GDP. It is obvious that the national health system (NHS) and the national system of social care cannot afford further financing given that the deficits of the NHS to the pharmaceutical industry reach $€ 2.66$ billion. Even more, when total health expenditure is $€ 21$ billion, accounting for $9.2 \%$ of GDP whereas $47 \%$ refers to private and $53 \%$ to public 
health expenditure. The high share of private expenditure is mainly based on out of pocket payments that contribute to a significant economic burden to the lower income and disadvantaged, thus maintaining the socioeconomic inequalities in the access to health and social care.

It is obvious that the inequalities found in social protection and occupational rights of the volunteers' and the lower income population are discouraging for incorporating them in the official labour market. This is why unofficial employment is increasing in the country. This situation is expected to worsen not only the economic but also the political crisis, especially at this time, when the European Union Court of Justice has found that Greece was in contravention of the principles of equal rights and treatment in regards to men and women labor conditions. In addition, Greece was also in contravention in regards to public and private sector employees' rights as well as to the social funds benefits in the retirement status and occupational safety.

Recently, the government has announced a legislation reform of the social economy sector in order to ameliorate the occupational status of its employees and to promote volunteerism though the expansion of social rights to them. The measures expected to be taken are:

$>$ The creation of a flexible taxation system

$>$ The expansion of social security to volunteers

$>$ The introduction of a national accreditation system

$>$ The search for new sources of funding

It is believed that if this legislation becomes active, numerous positive changes will occur in the performance of the third sector in Greece. More analytically, new work places will be created, maybe more that $10 \%$ annually, competitiveness of the public sector monopoly will be increased and social cohesion and social capital will be further reinforced. Additionally, the quality of employment by preventing occupational accidents in a competitive and changing work environment, the expansion of social coverage to volunteers and the reinforcement of the volunteerism will be finally achieved. Further expected synergies will be the reduction of unemployment, economic growth and eventually the overcome of the economic crisis. Finally, the most significant advantage will be the achievement of real economic and social democracy.

\section{REFERENCES}

Alexander, V.D. (1998): "Environmental Constraints and Organizational Strategies: Complexity, Conflict, and Coping in the Nonprofit Sector". In Walter 
HEALTH SAFETY AND LIFE PROTECTION COVERAGE IN THE SOCIAL ECONOMY SECTOR IN GREECE: ANALYSIS OF EMPIRICAL FINDINGS

Powell and Elisabeth Clemens (Eds.), "Private Action and the Public Good", Yale University Press, New Haven, Connecticut.

Amin, A., Cameron, A., and Hudson, R.(2002): "Placing the Social Economy". London, Routledge.

Archambault, E. (1997): "The nonprofit sector in France", The Johns Hopkins Nonprofit Sector Series, Manchester UK.

Borzaga, C., Maiello, M.(1998): The development of Social Enterprises. In C. Borzaga and A.Santuari (Eds) "Social Enterprises and New Employment in Europe." Trento, Regione Autonoma Trentino-Alto Adige/European Commission DG5:73-92.

Byrne, D.(1999): "Social exclusion.", Buckingham, Open University Press.

Catterall, B., Lipietz, A., Hutton, W., and Girarder, H.(1996): "The Third Sector, urban regeneration and the stakeholder." City, 5(6): 86-97.

Chrisakis, M., Ziomas, D. (2002): "Social Economy and Employment: future options and necessary interventions Review of Labour Relations", 26(70) (in Greek).

Donoghue, F.(1998): "Defining the Nonprofit Sector: Ireland, Working Papers of the Johns Hopkins Comparative Nonprofit Sector Project, No 28", In Lester Salamon and Helmut Anheier (eds), Baltimore: The Johns Hopkins Institute for Policy Studies.

Geitona, M., Halkos, G., Zouboulakis, M., Kyriazis, N., Pararrigopoulos, X., and Economou, Ch.(2006): "Social Economy, volunteerism and labour market." In A. Afouxidis and K. Syrakoulis (eds) "Project Management in Non Governmental Organisations (NGOs)." Larissa, Propombos, 120-125 (in Greek).

Giddens, A.(2000): "The Third Way and its Critics." Cambridge, Polity Press.

Lipietz, A.(1992): "Towards a new economic order: postfordism, ecology and democracy." Oxford, Oxford University Press.

Lipietz, A.(1995): "Green Hopes: the future of political ecology." Cambridge, Polity Press.

Putman, R.(1993): "Making Democracy Work.", Princeton,N.J., Princeton University Press.

Rifkin, J.(1995):"The End of Work." New York, Putnam.

Rifkin, J.(2000): “The Age of Access”. New York, Tarcher/Putnam. 
Rimke, H.(2000): "Governing citizens through self-help literature." Cultural Studies, 14 (1): 61-78.

Ruddle, H. Mulvihill, R. (1999) "Reaching Out: Charitable Giving and Volunteering in the Republic of Ireland. The 1994 Study", Dublin: Policy Research Centre.

Ryan, W.P.(1999): "The new landscape for nonprofits." Harvard Business Review, 77(1), 127-136.

Salamon, L.M. (1995): "Partners in Public Service: Government - Nonprofit Relations in the Modern Welfare stat", Baltimore, The Johns Hopkins University Press.

Smith S. R., Lipsky M. (1993): "Nonprofits for Hire: The Welfare State in the Age of Contracting", Cambridge, Massachusetts, Harvard University Press.

Zannis, P.(2002): "The role of the Third Sector on fighting social exclusion." In D. Papadopoulos (Eds) Social Exclusion, Armos Editions, Athens, 73-81 (in Greek).

Zimmeck, M. (1998): "To Boldly Go: The Volunteering Sector and Voluntary Action in the New World of Work", RSA, London.

Ziomas, D. (2001): "The social economy sector in Greece." National Institute of Social Research Editions, Athens.

Zouboulakis, M., Halkos, G., Geitona, M., and Kevork, E.(2006). "Social Economy sector in the Region of Thessaly." Research Report. Department of Economics, University of Thessaly, Volos(in Greek). 